\title{
Pd-Catalyzed Asymmetric Conjugate Addition of Arylboronic Acids to Cyclic Enones
}

\section{Key words}

palladium

conjugate addition arylboronic acids

cyclic enones
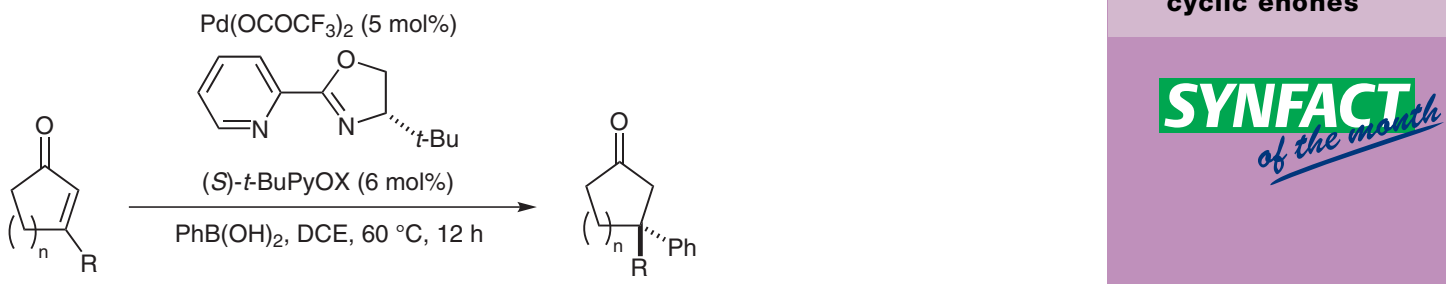

Selected examples:<smiles>CC1(c2ccccc2)CCC(=O)C1</smiles>

$84 \%$ yield, $91 \%$ ee<smiles>CCC1(c2ccccc2)CCCC(=O)C1</smiles>

$96 \%$ yield, $92 \%$ ee

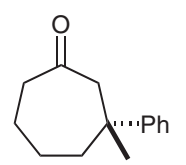

$85 \%$ yield, $93 \%$ ee

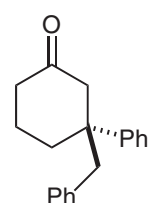

$74 \%$ yield, $91 \%$ ee<smiles>CC(C)C1(c2ccccc2)CCCC(=O)C1</smiles>

$86 \%$ yield, $79 \%$ ee<smiles>O=C1CCCC(c2ccccc2)(C2CC2)C1</smiles>

$68 \%$ yield, $88 \%$ ee

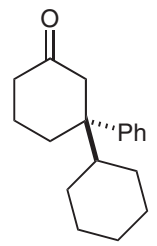

$86 \%$ yield, $85 \%$ ee
Significance: The authors report the first asymmetric palladium-catalyzed 1,4-addition of phenylboronic acids to $\beta$-substituted cyclic enones to construct quaternary centers in high yields and generally good enantioselectivities. The method is general for five-, six-, and seven-membered enones. Furthermore, a variety of electronically rich and poor arylboronic acids can be employed with moderate to excellent yields and fair to excellent asymmetric induction. Various substitution patterns at the $\beta$-position of the cyclic enones are tolerated without substantial loss of yield or enantioselectivity.
Comment: Although there are many related transformations, this is the first palladium-catalyzed variant for the construction of quaternary stereocenters in high yields and enantioselectivities. The ease with which the ligand can be synthesized is also noteworthy [the (S)-t-BuPyOX ligand can be prepared in two synthetic steps from commerically available materials]. The methodology exhibits broad functional group tolerance and can be performed in the presence of both air and water. This could prove to be a very useful contribution to the field. 